УДК 340.1

DOI https://doi.org/10.32850/sulj.2019.4.2.10

\title{
СПЕЦИФІКА ЗАКРІПЛЕННЯ ФУНКЦІЇ ПРАВА НА КОДИФІКАЦІЙНОМУ ТА ЗАКОНОДАВЧОМУ РІВНЯХ
}

Іваничук Р. A.

Метою статтіє загальнотеоретичніпроблемитапрактичні аспекти особливостей закріплення та розвитку функцій права на кодифікованому та законодавчому рівнях. Актуальність теми підтверджується тим, що сучасний період розвитку національної правової системи супроводжується багатьма складними динамічними процесами, вирішення яких потребує ефективного діючого механізму правотворення та посилення функціональної ролі права.

у статmі досліджено особливості юридичного закріплення функцій права на кодифікаційному та законодавчому ступенях. Визначено поняття функцій права та кодифікації законодавства. Розглянуто проблемні аспекти закріплення функцій права в основних кодифікованих галузях права, а також шляхи їх вирішення. Визначено, що функції права мають певне юридичне закріплення на кодифікаційному та законодавчому рівнях. Оскільки основними видами кодифікаційних актів $є$ основи законодавства і кодекси, тому на прикладі галузей вітчизняного законодавства автор проводить аналіз особливостей їх закріплення та реалізації. Функції права відображають своє юридичне закріплення в таких галузях права: конституційне право; цивільне право; сімейне право; трудове право; житлове право; екологічне право; адміністративне право; кримінальне право; цивільно-процесуальне право; кримінально-процесуальне право.

3'ясовано, що немає єдиної точки зору щодо визначення поняття «функція права». Так, у цивільно-процесуальному праві та кримінально-процесуальному праві, так само як і в інших галузях права, виділяються такі основні функціі права, як регулятивна, охоронна та виховна. Саме ці функції дістали відображення у відповідних законодавчих актах. Зроблено висновок, що закріплення функцій права на кодифікаційному рівні галузей права сприяє ефективному застосуванню та реалізації правових норм, налагодженню чіткого механізму правового регулювання суспільних відносин, наслідком чого є формування в суспільстві високого рівня правової культури громадян, розуміння ними позитивної або негативної поведінки.

Ключові слова: функції права, кодифікація законодавства, акти кодифікації законодавства України, правове регулювання.

Целью статьи являются общетеоретические проблемы и практические аспекты особенностей закрепления и развития функций права на кодифицированном и законодательном уровне. Актуальность темы подтверждается тем, что современный период развития национальной правовой системы сопровождается многими сложными динамическими процессами, решение которых требует эффективного действующего механизма правотворчества и усиления функциональной роли права.

В статье исследованы особенности юридического закрепления функций права на кодификационной и законодательной степенях. Определено понятие функций права и кодификации законодательства. Рассмотрены проблемные аспекты закрепления функций права в основных кодифицированных отраслях права, а также пути их решения. Определено, что функции права имеют определенное юридическое закрепление на кодификационном и законодатель- ном уровне. Поскольку основными видами кодификационных актов есть основы законодательства и кодексы, на примере отраслей отечественного законодательства автор провел анализ особенностей их закрепления и реализации. Функции права отражают свое юридическое закрепление в таких отраслях права: конституционное право; гражданское право; семейное право; трудовое право; жилищное право; экологическое право; административное право; уголовное право; гражданско-процессуальное право, уголовно-процессуальное право.

Выяснено, что нет единой точки зрения относительно определения понятия «функция права». Так, в гражданскопроцессуальном праве и уголовно-процессуальном праве, так же как и в других отраслях права, выделяются такие основные функции права, как регулятивная, охранная и воспитательная. Именно эти функции получили отражение в соответствующих законодательных актах. Сделан вывод, что закрепление функций права на кодификационном уровне отраслей права способствует эффективному применению и реализации правовых норм, налаживанию четкого механизма правового регулирования общественных отношений, следствием чего является формирование в обществе высокого уровня правовой культуры граждан, понимания ими положительного или отрицательного поведения.

Ключевые слова: функции права, кодификация законодательства, акты кодификации законодательства Украины, правовое регулирование.

The purpose of this article is the general theoretical problems and practical aspects of the peculiarities of securing and developing the functions of law at the codified and legislative level. The relevance of the topic is confirmed by the fact that the modern period of development of the national legal system is accompanied by many complex dynamic processes, the solution of which requires an effective current mechanism of lawmaking and strengthening the functional role of law. Thus, the article explores the peculiarities of the legal entrenchment of the functions of law at the codification and legislative stages.

The concept of the functions of law and codification of legislation is defined. The problems of fixing the functions of law in the main codified fields of law, as well as ways of their solution are considered. It is determined that the functions of law have some legal implications at the codification and legislative levels. Since the main types of codification acts are the basics of legislation and codes, so on the example of branches of domestic law we will analyze the features of their consolidation and implementation. Thus, the functions of law reflect their legal standing in areas of law such as: constitutional law; civil law; family law; labor law; housing law; environmental law; administrative law; criminal law; civil procedural law; criminal procedure law. It has been found that there is currently no single view as to the definition of the function of law.

Thus, in civil procedural law and criminal procedure law, as well as in other branches of law, such basic functions of law as regulatory, security and educational are distinguished. It was these functions that were reflected in the relevant legis- 
lation. It is concluded that the consolidation of the functions of law at the codification level of the branches of law promotes the effective application and implementation of legal norms, a clear mechanism of legal regulation of social relations, which results in the formation of a high level of legal culture of citizens in society, understanding of their positive or negative behavior.

Key words: functions of law, legislature, codification of legislature, acts of codifying legislature in Ukraine, legal reg. ulation.

Постановка проблеми та її актуальність. Сучасний період розвитку національної правової системи супроводжується багатьма складними динамічними процесами, вирішення яких потребує ефективного діючого механізму правотворення та посилення функціональної ролі права.

Аналіз останніх досліджень і публікацій. Серед науковців, які досліджували тематику, що стосувалася різних аспектів функцій права, кодифікаційної та правотворчої діяльності, $\epsilon$ Н. Оніщенко, О. Скакун, О. Зайчук, В. Цвік, М. Марченко, В. Ковальський, О. Петрішин, Ю. Шемшученко, С. Лисенков, А. Колодій, В. Копєйчиков, М. Кельман, О. Мурашин та інші. Однак питання, які належать до площини закріплення ірозвитку функцій права на кодифікаційному та законодавчому рівнях, ще не отримали належного наукового аналізу.

Метою статті $\epsilon$ загальнотеоретичні проблеми та практичні аспекти особливостей закріплення та розвитку функцій права на кодифікованому та законодавчому рівнях.

Виклад основного матеріалу. Перш ніж дослідити розвиток функцій права на кодифікаційному та законодавчому рівнях правового регулювання, потрібно з'ясувати значення таких термінів, як «функція» та «кодифікація».

Сутність права та його значення в житті суспільства нерозривно пов'язані з його функціями, які відображають правомірність влади. Право повинне забезпечувати інтереси суспільства. Воно має бути регулятором суспільних відносин і визначати обов'язкову поведінку всіх членів суспільства. Саме в такому випадку, вважає Л. Заморська, право буде позитивно впливати на поведінку суб'єктів правовідносин, а також на суспільні відносини [1, с. 4-6]. На думку юристів та науковців, право у суспільстві покликане узгоджувати протилежні інтереси різних соціальних суб'єктів, а також здійснювати допомогу у вирішенні різних соціальних суперечок із метою пошуку компромісу [2, с. 10-15].

У сучасній літературі поняття «функція» вживається в досить широких значеннях. Наприклад, у біології функція - це діяльність якогось одного органу або i всього організму (функція нирок, серця, печінки, жовчного міхура). У кібернетиці «функція» - це напрям дії якоїсь системи. Термін «функція» має досить багато значень, які характеризують різні динамічні структури [3, с. 49]. Це пов'язано з тим, що кожна наука, яка використовує це значення, має різні завдання. В загальному переважають випадки, де із функцією пов' язують вплив системи на окремі сторони середовища.

В юридичній літературі поняття «функція» характеризує передусім соціальну роль права. Натепер немає єдиної точки зору щодо визначення поняття «функція права». Над цим питанням працювало багато дослідників-науковців, серед них такі, як Н. Оніщенко, О. Скакун, О. Зайчук, В. Цвік, М. Марченко, В. Ковальський,
О. Петришин. Якщо узагальнити всі їхні погляди, то можна зробити висновок, що функція права - це соціальне призначення права або його вплив на суспільні відносини.

Також немає єдиної думки і щодо поділу функцій права, оскільки їх класифікують за різними ознаками. Залежно від сфери регульованих суспільних відносин та їх важливості виділяють основні (загальноправові) функції та неосновні, властиві окремим галузям права [4, с. 320]. Беручи за основу вплив права на суспільні відносини, розрізняють загальносоціальні та спеціальні (юридичні) функції [5, с. 225] або загальносоціальні та спеціальносоціальні функції [6, с. 228].

Найпоширенішою думкою серед науковців $\epsilon$ така, що функції права поділяються на загальносоціальні та спеціально-соціальні (юридичні) (С. Лисенков, А. Колодій, В. Ковальський, В. Копєйчиков, М. Кельман, О. Мурашин, О. Скакун та інші). До загальносоціальних функцій права належить ідеологічна, економічна, політична функції. Якщо ж розглядати функції права з юридичної (спеціально-юридична) точки зору, то їх поділяють на регулятивну і охоронну, оскільки праву як регулятору суспільних відносин найбільш притаманні регулятивні або охоронні властивості.

Об'єктом впливу регулятивної функції є нормальні, позитивні, корисні суспільні відносини, які право впорядковує шляхом: 1) закріплення сталих, розвинутих відносин у нормативних актах, гарантуючи у такий спосіб їх недоторканість (статистична функція); 2) заохочення, стимулювання розвитку тих суспільних відносин, які, відображаючи певні соціальні цінності, перебувають на етапі свого становлення (динамічна функція). Охоронна функція повинна захищати позитивні суспільні відносини, усуваючи соціально шкідливі і небезпечні діяння людей і їх об'єднань, відновлювати порушені права суб'єктів [7, с. 167-168]. Таким чином, прогресивний розвиток суспільства і держави передбачає ефективний механізм юридичного закріплення та реалізації функцій права, насамперед на конституційному та законодавчому рівнях.

Термін «кодифікація» складається із двох латинських словосполучень - "codex", що означає «книга", та “fасіо” (в перекладі «роблю») [8, с. 160]. Про кодифікацію нам відомо ще з XIX століття від англійського філософа та правознавця Дж. Бентама [9, с. 376]. Саме він дав ідею для створення одного кодексу, який був би зрозумілий для суспільства різних держав, оскільки має бути написаний доступноюдлявсіхмовою. Такожйшлося i про те, щоб такий кодекс не потребував тлумачення жодними органами, на те уповноваженими [10, с. 69].

Необхідно зазначити, що метою кодифікації $\epsilon$ вдосконалення систематизації нормативних актів, яка полягає у певній переробці змісту груп юридичних норм, що мають спільний предмет правового регулювання, а також вона об'єднує їх в один нормативно-правовий акт [8, с. 160]. Під час кодифікації до нового акту включаються діючі та нові норми, які вносять зміни у регулювання цієї сфери суспільних відносин $[11$, с. 140]. Можна сказати, що кодифікація - це підготовка і прийняття нових актів, які складаються із норм попередніх актів, що позитивно себе зарекомендували, та нових нормативних приписів. При кодифікації не тільки упорядковуються в потрібному порядку відповідні матеріали, але і переглядаються норми, які відо- 
бражаються у законах і підзаконних актах. Під час перегляду норм, які застаріли або вже неефективні, можуть бути скасовані та створені нові. Також кодифікація усуває прогалини, розбіжності та запобігає дублюванню в законодавстві. В більшості випадків кодифікуються норми, які мають довготривалий характер [9, с. 376]. Результатом кодифікації $\epsilon$ кодифікаційні акти, які поділяються на:

1. Основи законодавства.

2. Кодекси як результати узагальнення і систематизації законодавства на відповідну тематику [12, с. 58-59].

3. Статути та положення, які приймаються не лише законодавчими органами, але й іншими правотворчими органами [13, с. 140].

В Україні досить стрімко розвивається правотворча та законодавча діяльність, активно створюються нові нормативні акти, результатом чого $\epsilon$ зміни процесів правового регулювання. Якщо зараз не буде впорядковуватися вся ця оновлена нормативна база, то в майбутньому ми стикнемося із труднощами щодо пошуку і використання потрібних норм права. Оскільки зараз в Україні нестабільна економічна, фінансова та соціальна ситуація, тому наслідком цього можна вважати певні ознаки нестабільності нормопроектування, що негативно впливає на сучасну правову базу (велика кількість різних видів нормативно-правових актів, багато прогалин, суперечностей). Саме тому велику роль тут відіграє кодифікація. Тільки шляхом поетапної кодифікації і систематизації нормативно-правової бази всієї системи законодавства можна усунути перелічені вище недоліки.

Нерідко буває так, що органи державної влади при створенні правових норм використовують різні терміни, які на той момент уже $\epsilon$ застарілими або $є$ запозиченими чи навіть можуть не відповідати дійсності. Тому важливо дотримуватися термінологічної упорядкованості. Не менш важливим при кодифікації $\epsilon$ намагання враховувати та узгоджувати нові законодавчі акти із конституційними актами, а також максимально використовувати досвід світового законодавства [14, с. 7]. Отже, кодифікація має позитивний вплив на доступність законодавства, завдяки їй законодавство має правильне застосування та слугує важливим чинником правового виховання населення [14, с. 14].

Функції права мають певне юридичне закріплення на кодифікаційному та законодавчому рівнях. Оскільки основними видами кодифікаційних актів $\epsilon$ основи законодавства і кодекси, тому на прикладі галузей вітчизняного законодавства автор проведе аналіз особливостей їх закріплення та реалізації. Функції права відображають своє юридичне закріплення в таких галузях права: конституційне право; цивільне право; сімейне право; трудове право; житлове право; екологічне право; адміністративне право; кримінальне право; цивільно-процесуальне право; кримінально-процесуальне право.

Функції цивільного права - це напрями або види впливу правового регулювання на цивільно-правові відносини. Існує велика кількість функцій цивільного права, що потребує класифікації відповідно до якихось спільних рис. На жаль, у чинному законодавстві немає переліку таких функцій. Проте на практиці все ж виділилися основні функції цивільного права:

1) регулятивна, що відображається у регулюванні цивільних відносин завдяки правилам поведінки між їх учасниками. Регулятивна функція відображена у різних договорах цивільного права. Наприклад ст. 655 Цивільного кодексу описує договір купівлі продажу, який регулює відносини між двома сторонами, де одна сторона - продавець, а інша - покупець, перша сторона передає або зобов'язується передати товар чи майно у власність другій стороні, яка приймає товар і зобов'язана оплатити за нього певну суму [15]. Також регулятивна функція закріплюється в договорах дарування (ст. 717 цК України), найму (оренди) (ст. 759 цК України), страхування (ст. 979 ЦК України) [15]. Ще ця функція відображається в реалізації права власності, спадкового права, особистого немайнового блага (право на життя, право на сім'ю ) та не порушує прав інших осіб;

2) охоронна функція, яка захищає порушені цивільні права та інтереси громадян. Ця функція відображається в тих нормах, де передбачено відповідальність осіб, які завдали шкоди майновому або немайновому благу учасника цивільних правовідносин. Наприклад ст. 1166 ЦК України передбачає загальні підстави відповідальності за завдану майнову шкоду [15];

3) компенсаційна функція допомагає відновити порушені права та інтереси суб'єктів цивільних правовідносин, надаючи матеріальне відшкодування потерпілому. Ця функція юридично закріплена у ст. 16 ЦК України, де п. 8 передбачає «відшкодування збитків та інші способи відшкодування майнової шкоди» [15];

4) превентивна функція повинна не допускати скоєння фізичними та юридичними особами правопорушень. Вона інформує громадян про межі правомірних дій i про наслідки неправомірних дій. Завдяки тому, що існують норми про відповідальність, людство утримується від більшості правопорушень, усвідомлюється та визначається повага до права та інтересів інших осіб.

До основних функцій сімейного права відносять регулятивну, охоронну та виховну функції:

1. Регулятивна функція сімейного права відіграє особливе значення, оскільки регулювання відносин членів сім'ї і $\epsilon$ метою сімейного права. Прикладом юридичного закріплення цієї функції $€$ п. 2 ст. 1, ст. 7, ст. 8, ст. 9 Сімейного кодексу України [16].

2. Охоронна функція полягає в захисті та охороні прав і законних інтересів членів сімейних відносин. Зокрема, ст. 18 СК України передбачає і закріплює захист сімейних прав та інтересів, а в ст. 5 цього ж кодексу відображається державна охорона сім'ї.

3. Виховна функція - виховання поваги, любові та допомоги в сімейному колі, а також відповідальність за негативні наслідки по відношенню до сімейних цінностей [16].

Функції житлового права відображають вплив норм житлового права на розвиток суспільного життя. Вважають, що саме соціальна функція житлового права $\epsilon$ основною з функцій, оскільки з їі допомогою формується економічна політика в напрямі, необхідному для суспільства. Натепер головна мета такої політики - створити умови, щоб громадяни змогли реалізувати своє право на житло, розширити житлове будівництво, поліпшити утримання та схоронність житла.

Можна виділити ще такі функції житлового права, як охорону, регулятивну, виховну та попереджувальну. Ці та деякі інші функції юридично закріплені у певних нормативних актах житлового законодавства. Регулятивна функція житлового права регулює майнові та особисті немайнові відносини. Наприклад у Законі Укра- 
їни «Про приватизацію державного житлового фонду» регламентуються відносини, які стосуються переходу права державної власності у власність громадян України, а також права та обов'язки суб'єктів приватизації [17]. Охоронна функція житлового права захищає порушені та оспорювані права суб'єктів. Ця функція закріплена ст. 190 Житлового кодексу, яка передбачає відшкодування шкоди, заподіяної житловому фонду [18]. Виховна функція передбачає кримінальну, цивільну та адміністративну відповідальність, що відображається у ст. 189 Житлового кодексу. Попереджувальна функція житлового права знайшла своє відображення у статтях 116, 117 Житлового кодексу, які описують примусове виселення осіб із житла в разі вчинення ними правопорушення [18].

У кримінальному праві головними функціями $є$ регулятивна та охоронна. Прикладом регулятивної функції $\epsilon$ ст. 49 Кримінального кодексу, яка передбачає звільнення від кримінальної відповідальності у зв'язку із закінченням строків давності. Одним із таких способів держава регулює суспільні відносини, які виникли внаслідок вчинення злочину [19]. У статті 1 Кримінального кодексу відображена охоронна функція. Додатковими функціями кримінального права $\epsilon$ виховна, компенсаційна, заохочувальна, які теж відображені в Кримінальному кодексі.

У цивільно-процесуальному праві та кримінально-процесуальному праві, так само як і в інших галузях права, виділяються такі основні функції права, як регулятивна, охоронна та виховна. Саме ці функції дістали відображення у відповідних законодавчих актах. С. Алексєєв стверджує, що оскільки функції різні, то вони впливають на юридичний зміст законодавства та його внутрішню будову і визначають важливі елементи його структури [20, с. 194-195]. Так, регулятивна функція трудового права повинна регулювати відносини, які складають предмет трудового права [22].

Що стосується охоронної функції, то тут немає однієї думки науковців щодо визначення ії змісту. Наприклад, І.А. Кузнєцов стверджує, що в охоронної функції $\epsilon$ три самостійні сторони в реалізації: охорона державного (конституційного) ладу; запобігання порушенню законодавства; виявлення припинення вчинених правопорушень, покарання винних осіб [21, с. 58-59]. Однак охоронна функція проявляється не тільки в цих трьох аспектах. Насправді її прояви ще відображаються і у прийнятті нормативно-правових актів, одним із яких $\epsilon$ Закон України «Про охорону праці».

Охоронна функція також відображається уст. 235 КЗпП України: «У разі звільнення без законної підстави або незаконного переведення на іншу роботу, у тому числі у зв'язку з повідомленням про порушення вимог Закону України «Про запобігання корупції» іншою особою, працівник повинен бути поновлений на попередній роботі органом, який розглядає трудовий спір. При винесенні рішення про поновлення на роботі орган, який розглядає трудовий спір, одночасно приймає рішення про виплату працівникові середнього заробітку за час вимушеного прогулу або різниці в заробітку за час виконання нижчеоплачуваної роботи, але не більш як за один рік. Якщо заява про поновлення на роботі розглядається більше року не з вини працівника орган, який розглядає трудовий спір, виносить рішення про виплату середнього заробітку за весь час вимушеного прогулу» [22].
Виховна функція передбачає матеріальну і дисциплінарну відповідальність для винних, а за якісне виконання роботи - заохочення. За допомогою цієї функції створюється така особистість, яка зможе існувати у сучасному суспільстві. Ст. 140 КЗпП України відображає виховну функцію: «Трудова дисципліна на підприємствах, в установах, організаціях забезпечується створенням необхідних організаційних та економічних умов для нормальної високопродуктивної роботи, свідомим ставленням до праці, методами переконання, виховання, а також заохоченням за сумлінну роботу. У трудових колективах створюється обстановка нетерпимості до порушень трудової дисципліни, суворої товариської вимогливості до працівників, які несумлінно виконують трудові обов' язки. До окремих несумлінних працівників застосовуються в необхідних випадках заходи дисциплінарного і громадського впливу» [22].

Висновки. Так, закріплення функцій права на кодифікаційному рівні галузей права сприяє ефективному застосуванню та реалізації правових норм, налагодженню чіткого механізму правового регулювання суспільних відносин, наслідком чого $\epsilon$ формування у суспільстві високого рівня правової культури громадян, розуміння ними позитивної або негативної поведінки.

\section{Література}

1. Л.І. Заморська. Функції права: змістовно-теоретичний аналіз. Актуальні проблеми вітчизняної юриспруденціï. № 6/2015. С. 3-10.

2. Оніщенко Н.М. Правова система: проблеми теорії : [монографія] / К. : Ін-т держави і права ім. В.М. Корецького НАН України, 2002. 352 с.

3. Оніщенко Н.М. Проблеми ефективності законодавства: сучасна доктрина та потреби практики. Судова апеляція. 2006. № 2(3). С. 10-15.

4. Теорія держави і права. Академічний курс : [підручник] / за заг. ред. Н.М. Оніщенко, О.В. Зайчука. К. : Юрінком Інтер, 2006. 688 с.

5. Юридична енциклопедія: В 6 т. / Редкол.: Ю.С. Шемшученко (голова редкол.) та ін. К. : «Укр. енцикл.», 1998. Т. 6: Т-Я. 2004. 768 с: іл.

6. Скакун О.Ф. Теория государства и права : Учебник. Харьков : Консум; Ун-т внутр. дел, 2000. 704 с.

7. Теорія держави і права: Підручник / С.Л. Лисенков, А.М. Колодій, О.Д. Тихомиров, В.С. Ковальський. За ред. С.Л. Лисенкова. К. : Юрінком Інтер, 2005. 448 с.

8. Сучасна правова енциклопедія / О.В. Зайчук, О.Л. Копиленко, В.С. Ковальський [та ін.]; за заг. ред. О.В. Зайчука; Ін-т законодавства Верховної Ради України. 2-ге вид., перероблене і доповнене. К. : Юрінком Інтер, 2013. 408 с.

9. Скакун О.Ф. Теорія держави і права (енциклопедичний курс) : підручник. Видання 2-ге, перероблене і доповнене. Харків : Еспада, 2009. 752 с.

10. Керимов Д.А. Культура и техника законотворчества : монография М. : Юрид. лит-ра, 1991. 160 с.

11. Юридична енциклопедія: В 6 т. / Редкол.: Ю.С. Шемшученко (голова редкол.) та ін. К. : «Укр. енциклопедія», 1998. Т. 3. М. : Вид-во «Юридична думка», 2001. 792 с.

12. Меленко С.Г. Консолідація як вид систематизації нормативно-правових актів : дис. канд. юрид. наук: 12.00.01. Чернівці, 2002. 215 с.

13. Юридична енциклопедія: В 6 т. / Редкол.: Ю.С. Шемшученко (голова редкол.) та ін. К. : «Укр. енциклопедія», 1998. Т. 3. М. : Вид-во «Юридична думка», 2001. 792 с.

14. Систематизація законодавства України: проблеми та перспективи вдосконалення : Монографія. К. : Інсти- 
тут держави і права ім. В.М. Корецького НАН України, 2003. 220 c.

15. Цивільний кодекс України // [Електронний ресурс]. Режим доступу: https://zakon.rada.gov.ua/laws/ show/435-15.

16. Сімейний кодекс України // [Електронний ресурс]. Режим доступу: https://zakon.rada.gov.ua/laws/ main/2947-14.

17. Про приватизацію державного житлового фонду : Закон України // [Електронний ресурс]. Режим доступу: https: / /zakon.rada.gov.ua/laws/show/2482-12.

18. Житловий кодекс Української РСР // [Електронний ресурс]. Режим доступу: https://zakon.rada.gov.ua/laws/ main/5464-10.
19. Кримінальний кодекс України // [Електронний pecypc]. Режим доступу: https://zakon.rada.gov.ua/laws/ show/2341.

20. Алексеев С.С. Общая теория права. Москва : Юридическая лит-ра. Т. 1, 1981. 359 с.

21. Кузнецов И.А. Теория государства и прав : Учебное пособие. Волгоградская акад. гос. служб, 2010. 356 с.

22. Кодекс Законів про працю України з коментарями // [Електронний ресурс]. Режим доступу: https://legalexpert.in.ua/komkodeks/kzot.html.

Іваничук Р. A., здобувач кафедри теорії та історії держави і права Універсuтету Короля Данила 